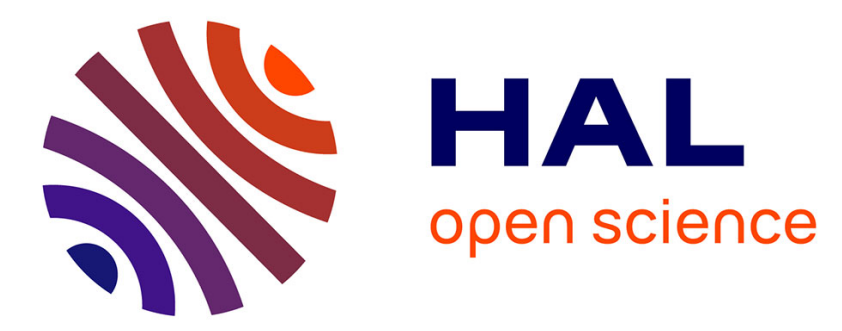

\title{
Ectomycorrhizal symbiosis helps plants to challenge salt stress conditions
}

Carmen Guerrero-Galán, Monica Calvo-Polanco, Sabine Dagmar Zimmermann

\section{To cite this version:}

Carmen Guerrero-Galán, Monica Calvo-Polanco, Sabine Dagmar Zimmermann. Ectomycorrhizal symbiosis helps plants to challenge salt stress conditions. Mycorrhiza, 2019, 29 (4), pp.291-301. 10.1007/s00572-019-00894-2 . hal-02139380

\section{HAL Id: hal-02139380 \\ https://hal.science/hal-02139380}

Submitted on 9 Feb 2021

HAL is a multi-disciplinary open access archive for the deposit and dissemination of scientific research documents, whether they are published or not. The documents may come from teaching and research institutions in France or abroad, or from public or private research centers.
L'archive ouverte pluridisciplinaire HAL, est destinée au dépôt et à la diffusion de documents scientifiques de niveau recherche, publiés ou non, émanant des établissements d'enseignement et de recherche français ou étrangers, des laboratoires publics ou privés.

$$
\text { Copyright }
$$


1 Ectomycorrhizal symbiosis helps plants to challenge salt stress conditions

2

3 Carmen Guerrero-Galán ${ }^{1,2}$, Monica Calvo-Polanco ${ }^{1}$ and Sabine Dagmar Zimmermann ${ }^{1 *}$

4

5

6

${ }^{1}$ BPMP, Univ Montpellier, CNRS, INRA, SupAgro, Montpellier, France.

7

$8{ }^{2}$ Present address: Centro de Biotecnología y Genómica de Plantas, Instituto Nacional de

9 Investigación y Tecnología Agraria y Alimentación (INIA), Universidad Politécnica de Madrid 10 (UPM), 28223 Pozuelo de Alarcón, Spain.

11

12

13

14 ORCID 0000-0002-5020-1447

15

16

17

18

19

20

21

22

23

24

25

26

27

Acknowledgments

28 CGG acknowledges the Ecole doctorale "GAIA" (University of Montpellier) for PhD

29 fellowships financed by the French Ministry of Higher Education and Research. 
31 Soil salinity is an environmental constraint for plants that is currently increasing worldwide.

32 The most common salt ions within soils, sodium and chloride, are considered as beneficial for 33 plant development in small amounts, although their excess induces stress in most plants. 34 Sodium is usually considered the most toxic ion in the couple, mainly because it causes an 35 imbalance in the electrochemical gradients and competes with potassium for membrane 36 transport systems and binding sites within cells. In addition, the sudden exposition of plants to 37 salinity induces osmotic stress that imbalances root water and nutrient absorption and transport.

38 Within the different strategies that plants use to cope with salinity, their association with beneficial soil microorganisms can play an important role in the adaptation to adverse environments. Among them, ectomycorrhizal fungi, specialized in colonizing the roots of woody plants, seem to have a protective effect on plants exposed to high amounts of salt. Although no precise mechanisms for this enhanced plant salt tolerance have been described yet, the improvement of plant water and mineral nutrition, and the restriction to sodium entrance and extrusion of toxic ions from the photosynthetic organs are proposed as possible strategies.

45 This review aims at summarizing the current knowledge accumulated on the role of ectomycorrhizal symbiosis in plant tolerance to salt stress.

\section{Keywords}

49 Ectomycorrhizal symbiosis, sodium, salt tolerance, trees, nutrient and water transport, 50 membrane transporters. 


\section{Introduction}

53 Salinity, understood as the excess of sodium $\left(\mathrm{Na}^{+}\right)$salts in the soil, is a detrimental condition for plant performance that is increasing nowadays and challenges both agricultural crops and natural ecosystems (Daliakopoulos et al. 2016). Salt stress induces both an osmotic and a toxic effect in plants which disturbs major plant metabolic processes and hampers plant water and nutrient balance. Exposure of plant roots to increasing $\mathrm{NaCl}$ will lead to competition of $\mathrm{Na}^{+}$ ions with potassium $\left(\mathrm{K}^{+}\right)$for its transporters so that $\mathrm{Na}^{+}$enters the plant cells through either non-specific or selective transport systems (Wu 2018). Thus, $\mathrm{Na}^{+}$concentrations will build up in the cytosol where it alters enzyme activity by displacement of the $\mathrm{Ca}^{2+}$ and $\mathrm{K}^{+}$ions of their binding sites (Cramer et al. 1985; Rodríguez-Navarro 2000). The abundance of $\mathrm{Na}^{+}$ions also changes the electrochemical gradient between both sides of the plasma membrane, affecting the energization of soil nutrient uptake (Tavakkoli et al. 2010). Palliating these negative effects diverts the energetic resources to detoxification, depleting other processes like nutrition, growth or reproduction (Munns and Tester 2008).

Maintaining $\mathrm{K}^{+}$contents in the cell cytoplasm and its movements in the vascular tissues is essential for salt-stressed plants to overcome the challenging environment (Shabala and Cuin 2008). Under salt stress, an initial massive influx of $\mathrm{Na}^{+}$in the root triggers a membrane depolarization that provokes a $\mathrm{K}^{+}$efflux from the cytosol (Shabala et al. 2006), accompanied by an increase in $\mathrm{K}^{+}$storage in the vacuole (Jiang et al. 2010). The drop in the cytosolic $\mathrm{K}^{+}$ level induces high affinity transporters to boost the uptake from the roots (Shabala 2017). In order to prevent $\mathrm{Na}^{+}$from reaching the photosynthetic organs, plants try to minimize its accumulation in the tissues through changes in gene expression and protein function of membrane transporters that aim at reducing the $\mathrm{Na}^{+}$uptake and at limiting its allocation to the leaves, by extruding it out from root cells or into the vacuoles.

One of the first responses of plants to salinity will be the closure of stomata, the reduction of transpiration, and the adjustment of the root water uptake. It is commonly accepted that water is transferred from the soil to the root through two main paths, the cell wall continuum (apoplastic path) and through the cell-to-cell path (symplastic path) which includes the transfer of water through plasmodesmata and plasma membranes using specialized water channel proteins called aquaporins. Aquaporins are membrane intrinsic proteins (MIPs) present in all species, including fungi and plants (Nehls and Dietz 2014; Verdoucq and Maurel 2018). Under different stresses including salinity, water uptake has been mainly attributed to the tight regulation of aquaporins (Boursiac et al. 2005; Afzal et al. 2016). Plant cells also accumulate compatible osmolytes or osmoprotectants. Although the role of compatible osmolytes has not 
been fully unravelled, it has been observed that they protect against oxidative stress inside the cells (Singh et al. 2015). Moreover, several studies have demonstrated that the overexpression of genes leading to increased accumulation of these solutes can confer on plants the ability to tolerate salinity (Parihar et al. 2015), and also, compatible solutes will alter how water is uptaken by the roots (Aroca et al. 2012; Calvo-Polanco et al. 2014).

Taking all this into account, we observe that plants are not devoid of defence mechanisms against salinity, at least in the short term. However, in the long run, these responses may not be enough against a sustained stress and require further physiological, ecological and evolutionary adaptations. This is the case of root symbioses, such as those established with mycorrhizal fungi, in which the microorganism improves plant water uptake and mineral nutrition. The extension of the exchange surface provided by the mycelium is an important factor in the enhanced absorption of water and nutrients of mycorrhizal plants as the hyphae are able to penetrate narrower pores (Bogeat-Triboulot et al. 2004; Lehto and Zwiazek 2011). Another beneficial effect is the improvement of soil structure that facilitates plant rooting (Rillig and Mummey 2006). All this translates in a stronger growth and higher biomass accumulation in mycorrhizal plants, which have a better fitness and consequently adapt better to challenging environments than in non-mycorrhizal conditions (Smith and Read 2008). So far, most information on the beneficial effects of mycorrhizal plant-fungal interactions in plant tolerance to salinity has been gathered from arbuscular mycorrhizal symbiosis revealing several mechanisms involved (Evelin et al. 2009; Lenoir et al. 2016). Other symbioses, as the ectomycorrhizal interactions specific to ligneous species, have evolved in many fungal and plant lineages independently, contrarily to arbuscular mycorrhiza, which is considered a plesiomorphy of plants (Field et al. 2015). This evolutionary diversity implies that the association with ectomycorrhizal fungi can have multiple functional roles in the physiology of the host. Little is known about ectomycorrhizal fungi concerning the mechanisms that contribute to alleviation of the effects of salinity on their host plants. In this review we present the research carried out thus far in this field and the main conclusions we can draw from them.

\section{Ectomycorrhizal fungi and the tolerance of plants to salt stress}

\section{Soil fungi differ greatly in their behaviour in saline environments}

The tolerance of fungi to salt stress has been often screened by measuring their capability to adapt and grow in a culture medium supplemented with $\mathrm{NaCl}$. Some extremophiles can grow at saturating concentrations of $\mathrm{NaCl}$ in their natural environments (Gunde-Cimerman et al. 2009), whereas others are extremely sensitive. Regarding salt tolerance of ectomycorrhizal 
120 fungal species, differences have been described between the two major phyla (Tresner and 121 Hayes 1971): as a general trend, Basidiomycota are less adapted to saline conditions than 122 Ascomycota, but some species are able to support relatively high $\mathrm{NaCl}$ concentrations (Zalar et 123 al. 2007). As a matter of fact, there are only 21 marine species of filamentous Basidiomycota, 124 very scarce compared to the 805 marine species of filamentous Ascomycota (Jones et al. 2015). 125 Overall, the salinity tolerance trait has been most studied in Basidiomycota. It is not necessarily 126 linked to specific clades but is found frequently in members of the same species or even the 127 same genus.

Ectomycorrhizal fungi are not usually found in environments of extreme salinity, such as salt ponds, and it is unlikely that they play a role in hypersaline environments, since 130 halophytic plants are mostly herbaceous and non-mycorrhizal (Brundrett 2009, 2017), 131 However, they have been shown to be able to adapt to saline environments, and to adapt and 132 grow in a culture medium supplemented with $\mathrm{NaCl}$ by in vitro tests. These tests on salinity 133 tolerance of different fungal strains (Table 1) were achieved at $\mathrm{NaCl}$ concentrations of 120-800 $134 \mathrm{mM}$ of e.g. Hebeloma sp. or Laccaria sp. (Hutchison 1990; Kernaghan et al. 2002), and of 135 isolates of the same species as Paxillus involutus (Zhang et al. 2008), Suillus spp. (Hutchison 1990; Dixon et al. 1993; Bois et al. 2006a; Tang et al. 2009; Obase et al. 2010), and Pisolithus sp. (Matsuda et al. 2006). In all cases, ion toxicity seems to be responsible for most of the negative effects observed on fungal growth, compared to the osmotic component due to the abundance of solutes in the environment (Dixon et al. 1993; Chen et al. 2001; Kernaghan et al. 2002; Bois et al. 2006a).

Also, some ectomycorrhizal fungi seem to have evolved towards salt tolerance and their growth can even be stimulated by the application of moderate $\mathrm{NaCl}$ concentrations in the range of 25-50 mM (Dixon 1993; Bois et al. 2006a; Matsuda et al. 2006) or higher (Zhang et al. 2008;

144 Obase et al. 2010). Recent studies using genomic techniques, have detected how populations of the ectomycorrhizal fungus Suillus brevipes in North America are able to adapt to stress associated with climate regimes and abiotic environments (Branco et al. 2015, 2017). Ectomycorrhizal fungi improve the tolerance of plants to salt stress with different strategies

149 Thus far, few studies have shown improved plant salt stress tolerance by ectomycorrhizal fungi compared to arbuscular mycorrhizal symbiosis. The effect of the presence of ectomycorrhizal fungi in alleviation of stress symptoms seems to be fungus- and/or host-dependent. Dixon et al. (1993) examined ectomycorrhizal Pinus taeda seedlings and found different responses depending on the fungal inoculum. Whereas $\mathrm{Na}^{+}$salts inhibited mycorrhization by some of the 
fungal species tested, root colonization by Pisolithus tinctorius and Laccaria laccata was not

155 affected under $80 \mathrm{mM}$. Also, a positive effect on biomass accumulation was found at mild salt stress $(20-40 \mathrm{mM} \mathrm{NaCl})$ on the seedlings mycorrhized with relatively salt-tolerant fungi. Other studies have tried to look into further physiological details, particularly the nutritional status of the plant to understand the specific processes for adaptation (see below). Complementarily to mineral and water nutrition, other processes, such as the activation of stress response pathways (metabolites, hormones) by ectomycorrhizal colonization can also play a role in the positive effect against environmental stresses (Luo et al. 2009; Ma et al. 2014).

The mechanisms responsible for the enhancement of plant tolerance to salt stress by ectomycorrhizal fungi are still unclear and several strategies could be involved. First, there is an undeniable redistribution of $\mathrm{Na}^{+}$ions in salt-stressed mycorrhizal plants compared to their non-inoculated counterparts. It seems crucial for survival that $\mathrm{Na}^{+}$does not reach the photosynthetic tissues, and this protective effect has been found in seedlings inoculated with salt-tolerant fungi. As a general rule, ectomycorrhizal seedlings subjected to salt stress were able to load less $\mathrm{Na}^{+}$to the shoots when inoculated with Hebeloma spp. (Muhsin and Zwiazek 2002a; Nguyen et al. 2006; Calvo-Polanco et al. 2008a, 2008b), Laccaria bicolor (Bois et al. 2006b; Nguyen et al. 2006; Calvo-Polanco et al. 2008b) and Suillus tomentosus (Calvo-Polanco et al. 2008a). This effect could be linked to the strong extrusion $\mathrm{Na}^{+}$by the fungus observed in Populus $x$ canescens - P. involutus symbioses (Li et al. 2012). In order to limit translocation of toxic $\mathrm{Na}^{+}$to the aerial parts, a successful strategy of plants is the storage of $\mathrm{Na}^{+}$in the root apoplasm, rather than in the vacuoles of root cells, avoiding its entrance into the symplastic pathway (Ottow et al. 2005). It is very likely that the $\mathrm{Na}^{+}$accumulated in the root tissues is retained by the fungus, in order to protect the photosynthetic apparatus of the plant to keep its production of carbon compounds.

These findings indicate that some ectomycorrhizal fungi function as a sort of "buffer" or physical barrier between the external medium and the root in order to avoid the transfer of toxic $\mathrm{Na}^{+}$ions into the root cortex. Following this idea, Langenfeld-Heyser et al. (2007) analysed $P$. $x$ canescens inoculated with $P$. involutus and found that the fungus did not change the $\mathrm{Na}^{+}$and chloride $\left(\mathrm{Cl}^{-}\right)$contents in the root cell walls, particularly in those of the xylem vessels, but somehow the fungus delayed the transfer of $\mathrm{Na}^{+}$to the shoot. An intermediate result was obtained by Ma et al. (2014) with two strains of $P$. involutus, one symbiotic and one nonsymbiotic. The inoculation of $P$. $x$ canescens with each of the $P$. involutus lines impaired $\mathrm{Na}^{+}$ translocation to the shoot, even though one of the lines does not form functional mycorrhizae. Although these results seem somehow contradictory, these studies have been done with 
different ectomycorrhizal fungi on distant plant species, gymnosperms and angiosperms, that

189 do not necessarily have the same root and mycorrhizal structure and therefore it is expected that the mechanisms of salt storage and transfer may differ.

\section{Ectomycorrhizal fungi improve plant mineral nutrition to alleviate salt stress}

193 The exclusion of $\mathrm{Na}^{+}$from sensitive tissues is commonly accepted to be tightly related to $\mathrm{K}^{+}$ 194 contents. Both ions are physico-chemically similar (Benito et al. 2014) and can be transported partly by the same membrane proteins, but their roles and effects in plant cells are completely different. Potassium is an essential macronutrient for plants, in which it is kept at high concentrations (100-200 mM) to play many cellular and physiological roles, from membrane energization to photosynthesis (Ahmad and Maathuis 2014; Dreyer et al. 2017). On the other hand, $\mathrm{Na}^{+}$is only beneficial in small amounts (in the nano- or micromolar range) and its excess is harmful for plant tissues, except in some particular cases (Hasegawa et al. 2000). In salt stress conditions, plants can suffer from $\mathrm{K}^{+}$deficiency due to the competition with $\mathrm{Na}^{+}$for uptake systems at the plasma membrane (Botella et al. 1997). It has been demonstrated that ectomycorrhizal fungi contribute to $\mathrm{K}^{+}$nutrition of plants (Jentschke et al. 2001) especially under conditions of $\mathrm{K}^{+}$starvation (Garcia et al. 2014). Some species are able to improve the $\mathrm{K}^{+}$ content in the leaves of their host, especially in unfavourable conditions. This has been observed in the symbiotic models $P$. involutus $-P$. $x$ canescens (Langenfeld-Heyser et al. 2007; Luo et al. 2009), Scleroderma bermudense - Coccoloba uvifera (Bandou et al. 2006) and Hebeloma crustuliniforme - Picea glauca (Muhsin and Zwiazek 2002a). Li et al. (2012) demonstrated by flux measurements that $\mathrm{K}^{+}$homeostasis was maintained by $P$. involutus in salt stressed poplar, thanks to the reduction of the salt-induced leakage of $\mathrm{K}^{+}$and to the contribution of the fungus to the host's absorption. Thus, an adequate $\mathrm{K}^{+}$nutrition enhanced by the ectomycorrhizal symbiosis seems to be crucial for a better adaptation of plants to environmental stresses, and in particular to salinity (Munns and Tester 2008; Wang et al. 2013).

Another strategy against the detrimental effects of high levels of salts is given by the advantageous effects of the presence of ectomycorrhizal fungi in the improvement of the general mineral nutrition of the plant. Indeed, some ectomycorrhizal fungi are able to keep the seedlings in a healthier state, for example by increasing the absorption of $\mathrm{Ca}^{2+}$, which is related as well to the $\mathrm{K}^{+} / \mathrm{Na}^{+}$ratio in the tissues (Ma et al. 2014), or by maintaining high phosphorus and nitrogen contents in the seedlings (Muhsin and Zwiazek 2002a). Luo et al. (2011) also found evidence that ectomycorrhizal poplar ( $P$. involutus) conserved a better nutritional status, which led to a reduced stress response and higher photosynthetic activity. A relative effect has 
222 also been observed in plants that are adapted to saline environments, such as the tropical

223 seagrape C. uvifera (Bandou et al. 2006), whose ectomycorrhizal roots efficiently excluded $\mathrm{Na}^{+}$

224 and $\mathrm{Cl}^{-}$ions and enhanced the absorption of phosphorus. However, no changes in the

225 phosphorus content of salt-stressed mycorrhizal plants have been also reported (Langenfeld-

226 Heyser et al. 2007).

\section{Ectomycorrhizal fungi can regulate plant water transport under salt stress}

229 In addition to the effects of salinity in ion homeostasis, $\mathrm{NaCl}$ is a known inhibitor of aquaporin230 mediated water transport in roots (Boursiac et al. 2005; Lee et al. 2010) and is also related to 231 the reduction of plant transpiration. The inoculation of seedlings with ectomycorrhizal fungi 232 keeps them in an overall healthier transpiration rate (Muhsin and Zwiazek 2002b; Bois et al. 233 2006b; Calvo-Polanco et al. 2008b). Different studies in AM fungi (Barzana et al. 2015; Calvo234 Polanco et al. 2016) and ectomycorrhizal fungi (Marjanović et al. 2005; Hacquard et al. 2013; 235 Navarro-Ródenas et al. 2013; Xu et al. 2015; Peter et al. 2016) have already pointed out the

236 role of mycorrhizal fungi in modifying the expression and abundance of plant aquaporins under 237 different soil environmental conditions. The up-regulation of these traits has been usually linked 238 to an increase in the water transport capacity of plants (Xu et al. 2015), specially under stress 239 (Barzana et al. 2015; Calvo-Polanco et al. 2016). However, in some cases, ectomycorrhizal 240 symbiosis had no or even a negative effect on the root hydraulic conductivity (Calvo-Polanco 241 et al. 2011; Xu et al., 2016), but the specific processes responsible are still unknown. Taken 242 together, the role of fungal aquaporins as modulators of water transport in stress conditions 243 cannot be dismissed, as it might be one of the key factors for salt stress tolerance in combination 244 with activation of pathways that involves hormones and stress signal molecules and that will need future studies.

\section{Membrane transport systems involved in symbiotic tolerance to salt stress}

248 Molecular mechanisms responsible for plant salinity tolerance mediated by ectomycorrhizal 249 symbiosis include membrane transport systems both at the fungal and at the plant root 250 membranes. Such membrane transporters would be critical for all the three adaptation strategies 251 shown by ectomycorrhizal symbioses, for $\mathrm{Na}^{+}$exclusion, $\mathrm{K}^{+}$nutrition and water transport (Fig. $2521)$.

253 Regarding the barrier function of the fungus, it would be particularly interesting to 254 characterize the membrane transport systems responsible for $\mathrm{Na}^{+}$fluxes. The ENA1 ATPase 255 (Rodríguez-Navarro and Benito 2010) and the $\mathrm{Na}^{+} / \mathrm{H}^{+}$antiporters Nha-like (Bañuelos et al. 
1998; Proft and Struhl 2004), both involved in tolerance to $\mathrm{NaCl}$ in fungi, are promising

257 candidates for $\mathrm{Na}^{+}$efflux from the fungus to the external medium. The first evidence for this 258 has been found in $S$. brevipes from a salinity area that had adapted to tolerate salt stress by developing differential genomic regions including a gene encoding a membrane $\mathrm{Na}^{+} / \mathrm{H}^{+}$ antiporter (Branco et al. 2015). These results are also supported by experiments by Li et al.

261 (2012), in which the pharmacological inhibition of $\mathrm{Na}^{+} / \mathrm{H}^{+}$antiporters of $P$. involutus had an 262 effect on its salt-induced extrusion of $\mathrm{Na}^{+}$. These results are also supported by experiments by $263 \mathrm{Li}$ et al. (2012), in which the pharmacological inhibition of $\mathrm{Na}^{+} / \mathrm{H}^{+}$antiporters of $P$. involutus 264 had an effect on its salt-induced extrusion of $\mathrm{Na}^{+}$. It is also possible that the excess of $\mathrm{Na}^{+}$in the fungus is stored in vacuoles or endosomes rather than in the cytosol, by members of the VNX and NHX transporter families (Nass et al. 1997; Cagnac et al. 2007).

Potassium transporters and channels of the fungal and plant partners of the symbiosis could cause a differential distribution of this ion within the mycorrhizal plant (Garcia and Zimmermann, 2014). Selective fungal uptake transport systems, belonging to the Trk or HAK families, could fight the excess of external $\mathrm{Na}^{+}$with a higher selective absorption than plant transporters. A further filter would be applied by the $\mathrm{K}^{+}$-selective channels that are thought to release $\mathrm{K}^{+}$into the plant apoplasm (Guerrero-Galán et al. 2018a, b). It is also likely that fungi face the $\mathrm{K}^{+} / \mathrm{Na}^{+}$imbalance through storage of $\mathrm{K}^{+}$in the vacuole or Golgi and the Kha1 transporters could play this role. It is also noteworthy that, due to their similarity, $\mathrm{Na}^{+}$and $\mathrm{K}^{+}$ can be permeated through the same transport systems with different affinities (Ariño et al. 2010).

In parallel to the $\mathrm{K}^{+}$nutrition, fungal and plant aquaporins mediating water transport (Fig. 1) and their regulation are involved in salt stress responses of ectomycorrhizal plants as summarized above. These molecular players are well described in plants (Verdoucq and Maurel 2018) and have been identified in fungal genomes and partially characterized (Dietz et al. 2011; $\mathrm{Xu}$ et al. 2015; Peter et al. 2016). For now, seven aquaporins have been found in the fungus $L$. bicolor, of which $L b \mathrm{AQP} 1$ is necessary for the development of functional ectomycorrhizae in trembling aspen (Navarro-Ródenas et al. 2015). Interestingly, in transcriptomic analysis of the symbiotic couple Cenococcum geophilum-Pinus sylvestris cultured under drought, one aquaporin (Cenge3:604158) was up-regulated, suggesting that the fungus may help the plant to cope with decreased water absorption or compensate the inhibition of plant aquaporins, although no physiological differences with non-inoculation controls was reported (Peter et al. 2016). In the future, discoveries in the area of fungal genomics will open new horizons in the 
study of plant-fungal symbiosis and are expected to be critical for the improvement of plant adaptation to the presence of salt within the soil.

The role of ectomycorrhizal associations in salt stress tolerance and their use for reforestation

294 In controlled in vitro or greenhouse experiments it is relatively easy to apply inocula and to calculate the degree of root colonization. The fixed environmental conditions can be radically different from those found in the real environment, where the climate and the existing rhizospheric biodiversity can greatly change the result of the experiment (Weissenhorn et al. 2002; Onwuchekwa et al. 2014). It is possible that fungi selected and grown in laboratory conditions are less competitive than the pre-existing microorganisms, and disappear from the roots in a short time span (Onwuchekwa et al. 2014). In addition, although the effect of ectomycorrhizae in growing seedlings is evident, it is still unknown to what extent ectomycorrhizal fungi can improve salt tolerance of adult trees.

However, some research aimed to apply ectomycorrhizal symbiosis on plant seedlings intended for ecological restoration of degraded areas, for example in the saline-alkaline soils contaminated by composite tailing residues of bitumen extraction. In these areas, plants are severely affected by accumulation of $\mathrm{Na}^{+}$, displaying reduced uptake of essential nutrients, such as $\mathrm{K}^{+}$and phosphorus, as well as leaf dieback (Renault et al. 1999). The first trials involved direct testing of salts or composite tailing water on axenic cultures of ectomycorrhizal fungi to assess which species and isolates were suitable for application in the field (Kernaghan et al. 2002; Bois et al. 2005). In parallel, several lots of autochthonous tree species were analyzed (Khasa et al. 2002; Bois et al. 2006a,b; Nguyen et al. 2006; Yi et al. 2008; Calvo-Polanco et al. 2008b, 2011). The optimal combinations of plants and fungi have been tested in experiments on oil sands reclamation sites with encouraging results with the prospect of a large-scale application. Inoculated seedlings had higher survival rates and biomass accumulation than the non-mycorrhizal plants, although the survival of the fungi in the root was not ensured (Onwuchekwa et al. 2014; Hankin et al. 2015). Research efforts are still in progress to select new pioneer symbiotic couples for land reforestation (Beaudoin-Nadeau et al. 2016).

To sum up, perspectives in this rather unexplored field of the use of ectomycorrhizal associations to struggle with salt stress could range from molecular approaches to application of ectomycorrhizal fungi in nurseries or forest cultures, offering exciting opportunities to fundamental and applied research. 


\section{References}

Afzal Z, Howton TC, Sun Y, Mukhtar MS (2016) The roles of aquaporins in plant stress responses. J Dev Biol 4:9. https://doi.org/10.3390/jdb4010009

Ahmad I, Maathuis FJM (2014) Cellular and tissue distribution of potassium: Physiological relevance, mechanisms and regulation. J Plant Physiol 171:708-714. https://doi.org/10.1016/j.jplph.2013.10.016

Ariño J, Ramos J, Sychorvá H (2010) Alkali metal cation transport and homeostasis in yeast. Microbiol Mol Biol Rev 74:95-120. http://dx.doi.org/10.1128/MMBR.00042-09

Aroca R, Porcel R, Ruiz-Lozano JM (2012) Regulation of root water uptake under abiotic stress conditions. J Exp Bot 63:43-57. https://doi.org/10.1093/jxb/err266

Bandou E, Lebailly F, Muller F, Dulormne M, Toribio A, Chabrol J, et al. (2006) The ectomycorrhizal fungus Scleroderma bermudense alleviates salt stress in seagrape (Coccoloba uvifera L.) seedlings. Mycorrhiza 16:559-565. https://doi.org/10.1007/s00572006-0073-6

Bañuelos MA, Sychrová H, Bleykasten-Grosshans C, Souciet JL, Potier S (1998) The Nha1 antiporter of Saccharomyces cerevisiae mediates sodium and potassium efflux. Microbiol 144:2749-2758. https://dx.doi.org/10.1099/00221287-144-10-2749

Bárzana G, Aroca R, Bienert GP, Chaumont F, Ruiz-Lozano JM (2014) New insights into the regulation of aquaporins by the arbuscular mycorrhizal symbiosis in maize plants under drought stress and possible implications for plant performance. Mol Plant Microbe Interact 27: 349-363. http://doi.org/10.1094/MPMI-09-13-0268-R

Beaudoin-Nadeau M, Gagné A, Bissonnette C, Bélanger P, Fortin J, Roy S, et al. (2016) Performance of ectomycorrhizal alders exposed to specific Canadian oil sands tailing stressors under in vivo bipartite symbiotic conditions. Can J Microbiol 7:1-7. https://doi.org/10.1139/cjm-2015-0703

Benito B, Haro R, Amtmann A, Cuin TA, Dreyer I (2014) The twins $\mathrm{K}^{+}$and $\mathrm{Na}^{+}$in plants. J Plant Physiol 171:723-731. https://doi.org/10.1016/j.jplph.2013.10.014

Bogeat-Triboulot MB, Bartoli F, Garbaye J, Marmeisse R, Tagu D (2004) Fungal ectomycorrhizal community and drought affect root hydraulic properties and soil adherence to roots of Pinus pinaster seedlings. Plant Soil 267:213-223. https://doi.org/10.1007/s11104-005-5349-7

Bois G, Piché Y, Fung M, Khasa D (2005) Mycorrhizal inoculum potentials of pure reclamation materials and revegetated tailing sands from the Canadian oil sand industry. Mycorrhiza 15:149-158. https://doi.org/10.1007/s00572-004-0315-4

Bois G, Bertrand A, Piché Y, Fung M, Khasa D (2006a) Growth, compatible solute and salt accumulation of five mycorrhizal fungal species grown over a range of $\mathrm{NaCl}$ concentrations. Mycorrhiza 16:99-109. https://doi.org/10.1007/s00572-005-0020-y

Bois G, Bigras F, Bertrand A, Piché Y, Fung M, Khasa D (2006b) Ectomycorrhizal fungi affect Picea glauca and Pinus banksiana in response to $\mathrm{NaCl}$ gradient.Tree Physiol 26:1185-1196. https://doi.org/10.1093/treephys/26.9.1185

Botella MA, Martínez V, Pardines J, Cerdá A (1997) Salinity induced potassium deficiency in maize plants. J Plant Physiol 150:200-205. https://doi.org/10.1016/S0176-1617(97)802039

Boursiac Y, Chen S, Luu DT, Sorieul M, van den Dries N, Maurel C (2005) Early effects of 
salinity on water transport in Arabidopsis roots. Molecular and cellular features of aquaporin expression. Plant Physiol 139:790-805. https://doi.org/10.1104/pp.105.065029

Branco S, Gladieux P, Ellison CE, Kuo A, LaButti K, Lipzen A, et al. (2015) Genetic isolation between two recently diverged populations of a symbiotic fungus. Mol Ecol 24: 2747-2758. http://doi.org/10.1111/mec.13132

Branco S, Bi K, Liao H-L, Gladieux P, Badouin H, Ellison CE, et al. (2017) Continental-level population differentiation and environmental adaptation in the mushroom Suillus brevipes. Mol Ecol 26: 2063-2076. https://doi.org/10.1111/mec.13892

Brundrett MC (2009) Mycorrhizal associations and other means of nutrition of vascular plants: Understanding the global diversity of host plants by resolving conflicting information and developing reliable means of diagnosis. Plant Soil 320:37-77. https://doi.org/10.1007/s11104-008-9877-9

Brundrett MC (2017) Global diversity and importance of mycorrhizal and nonmycorrhizal plants. Ecol Stud 230:533-556. https://doi.org/10.1007/978-3-319-56363-3_21

Cagnac O, Leterrier M, Yeager M, Blumwald E (2007) Identificationand characterization of Vnx1p, a novel type of vacuolar monovalent cation $/ \mathrm{H}^{+}$antiporter of Saccharomyces cerevisiae. J Biol Chem 282:24284-24293. https://doi.org/10.1074/jbc.M703116200

Calvo Polanco M, Zwiazek J, Voicu M (2008a) Responses of ectomycorrhizal American elm (Ulmus americana) seedlings to salinity and soil compaction. Plant Soil 308:189-200. https://doi.org/10.1007/s11104-008-9619-z

Calvo Polanco M, Zwiazek J, Jones M, MacKinnon M (2008b) Responses of mycorrhizal jack pine (Pinus banksiana) seedlings to $\mathrm{NaCl}$ and boron. Trees 22:825-834. https://doi.org/10.1007/s00468-008-0243-6

Calvo-Polanco M, Zwiazek JJ (2011) Role of osmotic stress in ion accumulation and physiological responses of mycorrhizal white spruce (Picea glauca) and jack pine (Pinus banksiana) to soil fluoride and $\mathrm{NaCl}$. Acta Physiol Plant 33:1365-1373. http://doi.org/10.1007/s11738-010-0670-z

Calvo-Polanco M, Sanchez-Romera B, Aroca R (2014) Mild salt stress conditions induce different responses in root hydraulic conductivity of Phaseolus vulgaris over-time. PloS One 9:e90631. https://doi.org/10.1371/journal.pone.0090631

Calvo-Polanco M, Sánchez-Castro I, Cantos M, García JL, Azcón R, Ruiz-Lozano JM, et al. (2016) Effects of different arbuscular mycorrhizal fungal backgrounds and soils on olive plants growth and water relation properties under well-watered and drought conditions. Plant Cell Environ 39:2498-2514. https://doi.org/10.1111/pce.12807

Chen DM, Ellul S, Herdman K, Cairney JWG (2001) Influence of salinity on biomass production by Australian Pisolithus spp. isolates. Mycorrhiza 11:231-236. https://doi.org/10.1007/s005720100126

Cramer GR, Läuchli A, Polito VS (1985) Displacement of $\mathrm{Ca}^{2+}$ by $\mathrm{Na}^{+}$from the plasmalemma of root cells: A primary response to salt stress? Plant Physiol 79:207-211. https://doi.org/10.1104/pp.79.1.207

Daliakopoulos I, Tsanis I, Koutroulis A, Kourgialas N, Varouchakis A, Karatzas G, et al. (2016) The threat of soil salinity: A European scale review. Sci Total Environ 573:727-739. https://doi.org/10.1016/j.scitotenv.2016.08.177

Dietz S, von Bülow J, Beitz E, Nehls U (2011) The aquaporin gene family of the ectomycorrhizal fungus Laccaria bicolor: Lessons for symbiotic functions. New Phytol 190, 927-940. http://doi.org/10.1111/j.1469-8137.2011.03651.x 
Dixon RK, Rao MV, Garg VK (1993) Salt stress affects in vitro growth and in situ symbioses of ectomycorrhizal fungi. Mycorrhiza 3:63-68. https://doi.org/10.1007/BF00210694

Dreyer I, Gomez-Porras JL, Riedelsberger J (2017) The potassium battery: A mobile energy source for transport processes in plant vascular tissues. New Phytol 216:1049-1053. https://doi.org/10.1111/nph.14667

Evelin H, Kapoor R, Giri B (2009) Arbuscular mycorrhizal fungi in alleviation of salt stress: A review. Ann Bot 104:1263-1280. https://doi.org/10.1093/aob/mcp251

Field KJ, Pressel S, Duckett JG, Rimington WR, Bidartondo MI (2015) Symbiotic options for the conquest of land. Trends Ecol Evol 30:477-486. https://doi.org/10.1016/j.tree.2015.05.007

Garcia K, Zimmermann SD (2014) The role of mycorrhizal associations in plant potassium nutrition. Front Plant Sci 5: 337. http://doi.org/10.3389/fpls.2014.00337

Garcia K, Delteil A, Conéjéro G, Becquer A, Plassard C, Sentenac H, et al. (2014) Potassium nutrition of ectomycorrhizal Pinus pinaster: Overexpression of the Hebeloma cylindrosporum HcTrkl transporter affects the translocation of both $\mathrm{K}^{+}$and phosphorus in the host plant. New Phytol 201:951-960. http://doi.org/10.1111/nph.12603

Guerrero-Galán C, Delteil A, Garcia K, Houdinet G, Conéjéro G, Gaillard I, et al. (2018a) Plant potassium nutrition in ectomycorrhizal symbiosis: Properties and roles of the three fungal TOK potassium channels in Hebeloma cylindrosporum. Environ Microbiol 20:1873-1887. http://doi.org/10.1111/1462-2920.14122

Guerrero-Galán C, Garcia K, Houdinet G, Zimmermann SD (2018b) HcTOK1 participates in the maintenance of $\mathrm{K}^{+}$homeostasis in the ectomycorrhizal fungus Hebeloma cylindrosporum, which is essential for the symbiotic $\mathrm{K}^{+}$nutrition of Pinus pinaster. Plant Signal Behav 13:e1480845. http://doi.org/10.1111/pce.13359

Gunde-Cimerman N, Ramos J, Plemenitaš A (2009) Halotolerant and halophilic fungi. Mycol Res 113:1231-1241. https://doi.org/10.1016/j.mycres.2009.09.002

Hacquard S, Tisserant E, Brun A, Legué V, Martin F, Kohler A (2013) Laser microdissection and microarray analysis of Tuber melanosporum ectomycorrhizas reveal functional heterogeneity between mantle and Hartig net compartments. Environ Microbiol 5:18531869. http://doi.org/10.1111/1462-2920.12080

Hankin S, Karst J, Landhäusser SM (2015) Influence of tree species and salvaged soils on the recovery of ectomycorrhizal fungi in upland boreal forest restoration after surface mining. Botany 93:267-277. http://doi.org/10.1139/cjb-2014-0132

Hasegawa PM, Bressan RA, Zhu JK, Bohnert HJ (2000) Plant cellular and molecular responses to high salinity. Annu Rev Plant Physiol Plant Mol Biol 51:463-499. http://doi.org/10.1146/annurev.arplant.51.1.463

Hutchison LJ (1990) Studies on the systematics of ectomyconhizal fungi in axenic culture. IV. The effect of some selected fungitoxic compounds upon linear growth. Can J Bot 68:21722178. https://doi.org/10.1139/b90-283

Jentschke G, Brandes B, Kuhn AJ, Schröder WH, Godbold DL (2001) Interdependence of phosphorus, nitrogen, potassium and magnesium translocation by the ectomycorrhizal fungus Paxillus involutus. New Phytol 149:327-337. http://doi.org/10.1046/j.14698137.2001.00014.x

Jiang X, Leidi EO, Pardo JM (2010) How do vacuolar NHX exchangers function in plant salt tolerance? Plant Signal Behav 5:792-795. https://dx.doi.org/10.4161/psb.5.7.11767

Jones EBG, Suetrong S, Sakayaroj J, Bahkali AH, Abdel-Wahab MA, Boekhout T, et al. (2015) 
Classification of marine Ascomycota, Basidiomycota, Blastocladiomycota and

Kernaghan G, Hambling B, Fung M, Khasa D (2002) In vitro selection boreal ectomycorrhizal fungi for use in reclamation of saline-alkaline habitats. Restoration Ecol 10:43-51. https://doi.org/10.1046/j.1526-100X.2002.10105.x

Khasa P, Hambling B, Kernaghan G, Fung M, Ngimbi E (2002) Genetic variability in salt tolerance of selected boreal woody seedlings. For Ecol Manage 165:257-269. https://doi.org/10.1016/S0378-1127(01)00623-5

Langenfeld-Heyser R, Gao J, Ducic T, Tachd P, Lu C, Fritz E, et al. (2007) Paxillus involutus mycorrhiza attenuate $\mathrm{NaCl}$-stress responses in the salt-sensitive hybrid poplar Populus $x$ canescens. Mycorrhiza 17:121-131. https://doi.org/10.1007/s00572-006-0084-3

Lee S, Calvo-Polanco M, Chung G, Zwiazek J (2010) Role of aquaporins in root water transport of ectomycorrhizal jack pine (Pinus banksiana) seedlings exposed to $\mathrm{NaCl}$ and fluoride. Plant Cell Environ 33:769-780 http://doi.org/10.1111/j.1365-3040.2009.02103.x

Lehto T, Zwiazek JJ (2011) Ectomycorrhizas and water relations of trees: A review. Mycorrhiza 21:71- 90 http://doi.org/10.1007/s00572-010-0348-9

Lenoir I, Fontaine J, Lounès-Hadj Sahraoui A (2016) Arbuscular mycorrhizal fungal responses to abiotic stresses: A review. Phytochem 123:4-15. https://doi.org/10.1016/j.phytochem.2016.01.002

Li J, Bao S, Zhang Y, Ma X, Mishra-Knyrim M, Sun J, et al. (2012) Paxillus involutus strains MAJ and NAU mediate $\mathrm{K}^{+} / \mathrm{Na}^{+}$homeostasis in ectomycorrhizal Populus $\times$canescens under sodium chloride stress. Plant Physiol 159:1771-1786. https://doi.org/10.1104/pp.112.195370

Luo Z, Janz D, Jiang X, Gö C, Wildhagen H, Tan Y, et al. (2009) Upgrading root physiology for stress tolerance by ectomycorrhizas: Insights from metabolite and transcriptional profiling into reprogramming for stress anticipation. Plant Physiol 151:1902-1917. https://doi.org/10.1104/pp.109.143735

Luo Z, Li K, Gai Y, Göbel C, Wildhagen H, Jiang X, et al. (2011) The ectomycorrhizal fungus (Paxillus involutus) modulates leaf physiology of poplar towards improved salt tolerance. Environ Exper Bot 72:304-311. https://doi.org/10.1016/j.envexpbot.2011.04.008

Ma X, Sun M, Sa G, Zhang Y, Li J, Sun J, et al. (2014) Ion fluxes in Paxillus involutusinoculated roots of Populus canescens under saline stress. Environ Exper Bot 108:99-108. https://doi.org/10.1016/j.envexpbot.2013.11.016

Marjanović Ž, Uehlein N, Kaldenhoff R, Zwiazek JJ, Weiss M, Hampp R, Nehls U (2005) Aquaporins in poplar: What a difference a symbiont makes! Planta 222:258-268. http://doi.org/10.1007/s00425-005-1539-z

Matsuda Y, Sugiyama F, Nakanishi K, Ito S (2006) Effects of sodium chloride on growth of ectomycorrhizal fungal isolates in culture. Mycoscience 47:212-217. https://doi.org/10.1007/S10267-006-0298-4

Muhsin TM, Zwiazek JJ (2002a) Colonization with Hebeloma crustuliniforme increases water conductance and limits shoot sodium uptake in white spruce (Picea glauca) seedlings. Plant Soil 238:217-225. https://doi.org/10.1023/A:1014435407735

Muhsin TM, Zwiazek JJ (2002b) Ectomycorrhizas increase apoplastic water transport and hydraulic conductivity in Ulmus americana seedlings. New Phytol 153:153-158. http://doi.org/10.1046/j.0028-646X.2001.00297.x

Munns R, Tester M (2008) Mechanisms of salinity tolerance. Annu Rev Plant Biol 59:651- 
681. https://doi.org/10.1146/annurev.arplant.59.032607.092911

Nass R, Cunningham KW, Rao R (1997) Intracellular sequestration of sodium by a novel $\mathrm{Na}^{+} / \mathrm{H}^{+}$exchanger in yeast is enhanced by mutationsin the plasma membrane $\mathrm{H}^{+}$-ATPase. Insights into mechanisms of sodium tolerance. J Biol Chem 272:26145-26152. https://doi.org/10.1074/jbc.272.42.26145

Navarro-Ródenas A, Bárzana G, Nicolás E, Carra A, Schubert A, Morte A (2013) Expression analysis of aquaporins from desert truffle mycorrhizal symbiosis reveals a fine-tuned regulation under drought. Mol Plant Microbe Interac 26:1068-1078. https://doi.org/10.1094/MPMI-07-12-0178-R.

Navarro-Ródenas A, Xu H, Kemppainen M, Pardo AG, Zwiazek JJ (2015) Laccaria bicolor aquaporin $L b \mathrm{AQP} 1$ is required for Hartig net development in trembling aspen (Populus tremuloides). Plant Cell Environ 38:2475-2486. http://doi.org/10.1111/pce.12552

Nehls U, Dietz S (2014) Fungal aquaporins: cellular functions and ecophysiological perspectives. Appl Microbiol Biotechnol 98:8835-8851. https://doi.org/10.1007/s00253014-6049-0

Nguyen H, Calvo-Polanco M, Zwiazek JJ (2006) Gas exchange and growth responses of ectomycorrhizal Picea mariana, Picea glauca, and Pinus banksiana seedlings to $\mathrm{NaCl}$ and $\mathrm{Na}_{2} \mathrm{SO}_{4}$. Plant Biol 8:646-652. https://doi.org/10.1055/s-2006-924106

Obase K, Lee JK, Lee SK, Lee SY, Chun KW (2010) Variation in sodium chloride resistance of Cenococcum geophilum and Suillus granulatus isolates in liquid culture. Mycobiol 38:225-228. https://doi.org/10.4489/MYCO.2010.38.3.225

Onwuchekwa N, Zwiazek J, Quoreshi A, Khasa D (2014) Growth of mycorrhizal jack pine (Pinus banksiana) and white spruce (Picea glauca) seedlings planted in oil sands reclaimed areas. Mycorrhiza 24:431-441. https://doi.org/10.1007/s00572-014-0555-X

Ottow E, Brinker M, Teichmann T, Fritz E, Kaiser W, Brosché M, et al. (2005) Populus euphratica displays apoplastic sodium accumulation, osmotic adjustment by decreases in calcium and soluble carbohydrates, and develops leaf succulence under salt stress. Plant Physiol 139:1762-1772. https://doi.org/10.1104/pp.105.069971

Parihar P, Singh S, Singh R, Singh VP, Prasad SM (2015) Effect of salinity stress on plants and its tolerance strategies: a review. Environ Sci Pollut Res 22:4056-4075. https://doi.org/10.1007/s11356-014-3739-1

Peter M, Kohler A, Ohm RA, Kuo A, Krützmann J, Morin E, et al. (2016) Ectomycorrhizal ecology is imprinted in the genome of the dominant symbiotic fungus Cenococcum geophilum. Nature Comm 7:12662. http://dx.doi.org/10.1038/ncomms12662

Porcel R, Aroca R, Ruiz-Lozano J (2012) Salinity stress alleviation using arbuscular mycorrhizal fungi. A review. Agron Sustain Dev 32:181-200. http://dx.doi.org/10.1007/s13593-011-0029-x

Proft M, Struhl K (2004) MAP kinase-mediated stress relief that precedes and regulates the timing of transcriptional induction. Cell 118:351-361. https://doi.org/10.1016/j.cell.2004.07.016

Renault S, Paton E, Nilsson G, Zwiazek JJ, MacKinnon MD (1999) Response of boreal plants to high salinity oil sands tailings water. J Environ Qual 28:1957-1962. https://doi.org/10.2134/jeq1999.00472425002800060035x

Rillig M, Mummey DL (2006) Mycorrhizas and soil structure. New Phytol 171:41-53. http://doi.org/10.1111/j.1469-8137.2006.01750.x

Rodriguez-Navarro A (2000) Potassium transport in fungi and plants. Biochim Biophys Acta 
1469:1-30. http://doi.org/https://doi.org/10.1016/S0304-4157(99)00013-1

Rodriguez-Navarro A, Benito B (2010) Sodium or potassium efflux ATPase a fungal, bryophyte, and protozoal ATPase. Biochim Biophys Acta 1798:1841-1853. https://doi.org/10.1016/j.bbamem.2010.07.009

Shabala S (2017) Signalling by potassium: another second messenger to add to the list? J Exp Bot 68:4003-4007. https://doi.org/10.1093/jxb/erx238

558

559

560

561

562

563

564

565

566

567

568

569

570

571

572

573

574

575

576

577

578

579

580

581

582

583

584

585

586

587

588

589

590

591

592

593

594

595

596

Shabala S, DemidchikV, Shabala L, Cuin TA, Smith SJ, Miller AJ, et al. (2006) Extracellular $\mathrm{Ca}^{2+}$ ameliorates $\mathrm{NaCl}$-induced $\mathrm{K}^{+}$loss from Arabidopsis root and leaf cells by controlling plasma membrane $\mathrm{K}^{+}$permeable channels. Plant Physiol 141:1653-1665. https://doi.org/10.1104/pp.106.082388

Shabala S, Cuin TA (2008) Potassium transport and plant salt tolerance. Physiol Plant 133:651669. https://doi.org/10.1111/j.1399-3054.2007.01008.x

Singh M, Kumar J, Singh S, Singh VP, Prasad SM (2015) Roles of osmoprotectants in improving salinity and drought tolerance in plants: a review. Rev Environ Sci Biotechnol 14:407-426. https://doi.org/10.1007/s11157-015-9372-8

Smith SE, Read D (2008) Mycorrhizal symbiosis (3rd ed.). New York: Academic Press. http://doi.org/http://dx.doi.org/10.1016/B978-012370526-6.50017-9

Tang M, Sheng M, Chen H, Zhang F (2009) In vitro salinity resistance of three ectomycorrhizal fungi. Soil Biol Biochem 41:948-953. https://doi.org/10.1016/j.soilbio.2008.12.007

Tavakkoli E, Rengasamy P, McDonald GK (2010) High concentrations of $\mathrm{Na}^{+}$and $\mathrm{Cl}^{-}$ions in soil solution have simultaneous detrimental effects on growth of faba bean under salinity stress. J Exp Bot 61:4449-4459. https://doi.org/10.1093/jxb/erq251

Tresner HD, Hayes JA (1971) Sodium chloride tolerance of terrestrial fungi. Appl Microbiol 22:210-213

Verdoucq L, Maurel C (2018) Plant Aquaporins. Adv Bot Res 87:25-56. https://doi.org/10.1016/bs.abr.2018.09.011

Wang M, Zheng Q, Shen Q, Guo S (2013) The critical role of potassium in plant stress response. Int J Mol Sci 14:7370-7390. https://doi.org/10.3390/ijms14047370

Weissenhorn I (2002) Mycorrhiza and salt tolerance of trees. EU-project MYCOREM (QLK3-1999-00097) the use of mycorrhizal fungi in phytoremediation. Final Report of Partner 9. Projects January 2000 - December 2002. https://www.servaplant.nl/new/wpcontent/uploads/2015/10/MycoremReport.pdf

Wu $\mathrm{H}$ (2018) Plant salt tolerance and $\mathrm{Na}^{+}$sensing and transport. Crop J 6:215-225. https://doi.org/10.1016/j.cj.2018.01.003

Xu H, Kemppainen M, El Kayal W, Lee SH, Pardo AG, Cooke JEK, Zwiazek JJ (2015) Overexpression of Laccaria bicolor aquaporin JQ585595 alters root water transport properties in ectomycorrhizal white spruce (Picea glauca) seedlings. New Phytol 205: 757770. http://doi.org/10.1111/nph.13098

Xu H, Cooke JEK, Kemppainen M, Pardo AG, Zwiazek JJ (2016) Hydraulic conductivity and aquaporin transcription in roots of trembling aspen (Populus tremuloides) seedlings colonized by Laccaria bicolor. Mycorrhiza 26:441-451. https://doi.org/10.1007/s00572016-0681-8

Yi H, Calvo-Polanco M, MacKinnon MD, Zwiazek JJ (2008) Responses of ectomycorrhizal Populus tremuloides and Betula papyrifera seedlings to salinity. Environ Exp Bot 62:357363. https://doi.org/10.1016/j.envexpbot.2007.10.008 
Zalar P, Hoog GS de, Schroers H-J, Crous PW, Groenewald JZ, Gunde-Cimerman N (2007) Phylogeny and ecology of the ubiquitous saprobe Cladosporium sphaerospermum, with descriptions of seven new species from hypersaline environments. Stud Mycol 58:157-183. https://dx.doi.org/10.3114/sim.2007.58.06

Zhang H, Li J, Chen S, Lu C, Wang R, Dai S (2008) Effect of $\mathrm{NaCl}$ on growth and ion relations in two salt-tolerant strains of Paxillus involutus. For Stud China 10:95-100. https://doi.org/10.1007/s11632-008-0025-7

\section{Legends of Figure \& Table}

Figure 1. Fungal membrane transport systems are probably involved in plant protection against salt stress through three different strategies. Three advantages of ectomycorrhizal symbiosis seem to be involved in a better stress tolerance of plants and membrane transport systems would play a role in all of them. First, $\mathrm{Na}^{+}$exclusion from the plant would depend on the extrusion of $\mathrm{Na}^{+}$from the extraradical mycelium to the soil through ENA ATPases and Nha transporters. The storage of the excess of $\mathrm{Na}^{+}$within vacuoles by $\mathrm{Vnx}$ transporters could also reduce the amount of $\mathrm{Na}^{+}$that reaches the plant tissues. The second strategy is the improvement of $\mathrm{K}^{+}$nutrition by the fungus, thanks to Trk and HAK uptake transporters. This ion would be transferred to the plant through TOK and/or SKC channels. Further uptake through ACU ATPases or storage in vacuoles or vesicles through Nhx and Kha transporters are also likely to occur. Finally, ectomycorrhizal fungi would help maintaining aquaporinmediated water transport, resulting in an improved water status of the symbiotic plant.

Table 1. Summary of the most studied salt-tolerant genera of ectomycorrhizal fungi: Hebeloma, Laccaria, Paxillus, Pisolithus, Rhizopogon and Suillus (Basidiomycota). *means that the studied isolate was not salt resistant. 